\title{
Organic carbon flux through a Delaware Bay salt marsh: tidal exchange, particle size distribution, and storms
}

\author{
Charles T. Roman*, Franklin C. Daiber \\ College of Marine Studies, University of Delaware, Newark, Delaware 19711, USA
}

\begin{abstract}
Organic carbon exchange via tidal transport between a 190 ha Spartina alterniflora marsh and Delaware Bay was quantified during 5 seasonal sampling periods in April, June, August, October, 1980 and January, 1981. Based on hourly samples collected over 3 consecutive tidal cycles, mean ebb tide concentrations of particulate organic carbon (POC) were higher than flood tide concentrations, except in January when the marsh surface and creeks were frozen. Mean ebb tide dissolved organic carbon (DOC) concentrations were greater than flood during all seasons, although the difference was only significant in August and January. Hourly concentrations were variable, ranging from 0.4 to 11.4 $\mathrm{mg} \mathrm{POC} \mathrm{l}^{-1}$ and 1.5 to $15.5 \mathrm{mg} \mathrm{DOC} \mathrm{l}^{-1}$. The relative degree of marsh surface flooding, current velocity and phytoplankton concentration are important factors influencing seasonal differences in mean flood and mean ebb concentrations of POC. A broad size spectrum of particulate detritus is available to estuarine consumers, with 60 to $84 \%$ of the total POC on both flood and ebb tides being $<20 \mu \mathrm{m}$ in size and the remaining material distributed fairly equally among larger fractions (>243 $\mu \mathrm{m}, 243-63 \mu \mathrm{m}$, 63-20 $\mu \mathrm{m}$ ). There was a net export of POC from Canary Creek marsh during all seasonal studies, except in January when exchange processes were much reduced. DOC was exported during all studies, except in June when the water volume transport estimate was significantly biased toward the flood direction. Annually, $1.05 \times 10^{5} \mathrm{~kg}$ was exported as POC and $1.97 \times 10^{5} \mathrm{~kg}$ as DOC. The influence of storms was not included in the annual organic carbon exchange budget. However, during an October tropical storm ebb-directed transports of POC and DOC were 5 to 6 times greater than during the normal ebb cycles monitored in October, suggesting that major coastal storms are significant to salt marsh organic material exchange processes. Elevated POC concentrations during 2 ebb cycles following an intense rainstorm in April suggest that these episodic events also represent important marsh-estuarine exchange mechanisms.
\end{abstract}

\section{INTRODUCTION}

An appreciation for the problems associated with estimating material fluxes through salt marshes has evolved over the past few decades. Nixon (1980) provides a review of salt marsh flux studies and states that most lack statistical interpretation of data and few adequately estimate water volume discharge, the key term to the direct estimation of material fluxes. All flux studies conducted to date have collectively contributed to our interpretation of salt marsh-estuarine exchanges and the ecological significance of these material exchanges. However, studies at only 4 coastal systems have clearly addressed the issues of creek hydrody-

- Present address: Narragansett Bay Project, 291 Promenade St, Providence, Rhode Island 02908, USA namics and error analysis (North Inlet, South Carolina, USA: Kjerfve et al. 1981, Whiting et al. 1985, Dame et al. 1986; Wachapreague, Virginia, USA: Boon 1978; Kiawah Island, South Carolina: Ward 1981; Great Sippewissett, Massachusetts, USA: Valiela et al. 1978). Boon (1975) compared 2 common methods for determining water volume discharge when conducting marsh flux studies (direct current measurements and area-height or hydroscopic model) and concluded that the direct approach is clearly preferable. The objective of this research was to add to this growing database whereby the net direction of salt marsh carbon fluxes, on seasonal and annual bases, could be estimated directly and with certainty.

This study quantifies organic carbon flux through a Delaware salt marsh where hydrographic aspects of water discharge have been carefully evaluated (Roman 
1984) and errors determined. Also included is size fractionation analysis of particulate organic materials, only previously reported for Georgia (USA) salt marshes (Odum \& de la Cruz 1967. Haines 1977), and further, an assessment of storm-generated organic carbon exchange.

\section{METHODS}

Study area. The Canary Creek salt marsh, dominated by Spartina alterniflora, is located in Lewes, Delaware (Sussex County), near the mouth of Delaware Bay, USA. Canary Creek is about $5 \mathrm{~km}$ long and drains ca 190 ha of marsh. The area is characterized by semidiurnal tides with a mean range of $1.3 \mathrm{~m}$ and a spring range of $1.6 \mathrm{~m}$. Mean salinity measured over complete tidal cycles near the mouth ranged from $22 \mathrm{ppt}$ in April to 30 ppt in January.

All sampling was from a $30 \mathrm{~m}$ wide cross-section located near the creek mouth. Mean depth was $1.5 \mathrm{~m}$ at mean low water. Current velocity at the cross-section was ebb-dominated, with peak ebb velocity recorded at $62 \mathrm{~cm} \mathrm{~s}^{-1}$ and peak flood velocity at $39 \mathrm{~cm} \mathrm{~s}^{-1}$. Based on 15 tidal cycles, the mean tidal prism was $2.09 \times$ $10^{5} \mathrm{~m}^{3}$.

Field sampling. Roman (1984) describes the method used to estimate water volume discharge through the cross-section. To account for cross-sectional velocity variations, a dense spatial array of current meters was established and simultaneous velocity measurements taken at hourly intervals over 3 complete tidal cycles. Based on the array data, best possible, or 'ideal', estimates of instantaneous volume discharge were obtained. Bivariate linear regression was then used to predict instantaneous volume discharge based on a velocity measurement from only one point within the cross-sectional array. It was determined that by employing a simplified spatial array (i.e. one measurement), instantaneous cross-sectional discharge could be estimated with an uncertainty of $\pm 11 \%$ when compared to the 'ideal' data set. Total tidal cycle discharge could be estimated with an error of only $\pm 7 \%$

While conducting a carbon flux study it would be ideal to estimate volume flux based on a dense current meter array and simultaneous water sample collections. However, establishing a current meter array at frequent intervals is often not practicable. Thus, the method described by Roman (1984) is useful in allowing the estimate of volume discharge from a simplified spatial array while maintaining acceptable error.

Sampling was conducted over 3 consecutive tidal cycles on each of 5 dates in April, June, August, and October 1980, and January 1981. Previous studies have documented considerable short-term variability in total volume discharge between consecutive tidal cycles (Erkenbrecher \& Stevenson 1978, Kjerfve \& Proehl 1979, Ward 1981, Chrzanowski et al. 1982). Diurnal inequality and wind effects are probably the salient factors contributing to these net fluxes. To account for some of this cycle-to-cycle variability, 3 consecutive tidal cycles were sampled in this study.

At hourly intervals current velocity was measured with a TSK flowmeter and tide height recorded. Instantaneous average cross-sectional velocity, computed after Roman (1984), multiplied by cross-sectional area yielded an estimate of instantaneous volume flux. A 11 water sample was then immediately collected for particulate organic carbon (POC) and dissolved organic carbon (DOC) determinations. At $2 \mathrm{~h}$ intervals and simultaneous with the above-mentioned 11 sample, duplicate 401 samples were collected. In the field, the 401 samples were washed through a series of nylon mesh sieves $(243 \mu \mathrm{m}, 63 \mu \mathrm{m}, 20 \mu \mathrm{m})$. An aliquot of the filtrate $(<20 \mu \mathrm{m}$ fraction) and the sets of sieves were taken to the laboratory. During periods of high particulate concentrations filtering of only 201 was needed to obtain an adequate amount of sample.

All water was collected with a submersible pump from mid-depth near the center of the sample crosssection. A preliminary tidal cycle study, with total suspended material collected from 3 depths along a vertical transect at mid-creek, revealed a homogeneous distribution (ANOVA, $F=0.956, p=0.379$, df $=29$ ), and thus, material concentrations from this one station were assumed representative of the entire cross-section.

Laboratory procedures. Material retained on a Whatman GF/C filter was analyzed for POC using a CHN analyzer (Hewlett-Packard Model 185B), following the method of Sharp (1974). The coefficient of variation or precision relative to the mean was $\pm 6 \%$. Filtrate passing through the $\mathrm{GF} / \mathrm{C}$ filter was analyzed for DOC by the IR-absorptive technique (Menzel \& Vaccaro 1964, Sharp 1973), with a relative precision of $\pm 5 \%$. For size fractionation, the material on one set of sieves was washed onto pretared $4.25 \mathrm{~cm}$ diameter $\mathrm{GF} /$ $\mathrm{C}$ filters, and dried to a constant weight at $60^{\circ} \mathrm{C}$. The filtrate that had passed through the sieves was similarly retained on a tared filter and dried. Dry weights and ash-free dry weights (obtained by combustion at $550^{\circ} \mathrm{C}$ for $2.5 \mathrm{~h}$ ) were determined for each size fraction. Materials from the second set of sieves were washed into pre-muffled aluminum pans and dried in vacuum desiccators until analyzed for organic carbon content with a CHN analyzer. A known volume of the filtrate was collected on a GF/C filter and $\mathrm{POC}$ analysis performed for the smallest fraction.

Chlorophyll a was determined fluorometrically using a Turner (model 111) fluorometer, following the 
laboratory methods of Strickland \& Parsons (1972). Relative precision was $\pm 6 \%$.

\section{RESULTS AND DISCUSSION}

\section{Seasonal concentrations - some considerations}

There was minimal variability of mean flood tide and mean ebb tide concentrations of POC and DOC among consecutive tidal cycles (Table 1). However, the few times when significant differences were noted (POC: June flood tides, August flood tides, January ebb tides; DOC: January ebb tides) justifies the need to sample over consecutive tidal cycles, thereby accounting for some of the inherent short-term variability. Monitoring consecutive tidal cycles becomes especially relevant when an ultimate objective is to assess seasonal trends.

The seasonal pattern of flood and ebb mean concentrations of POC appears relatively steady (Table 2). More northern systems generally show peak POC concentrations in late summer and fall (Woodwell et al. 1977, Valiela et al. 1978), corresponding to the period of vegetation senescence. At Canary Creek the potential for a consistently occurring pulse of POC to creek waters is apparently minimal as Roman \& Daiber (1984) report a fairly constant seasonal biomass of dead marsh vegetation. However, mean ebb concentrations are significantly greater than mean flood concentrations, with the difference derived, at least in part, from marsh vegetation. The lowest mean ebb concentration of POC occurred during the January study when Canary Creek was completely frozen, effectively limiting the potential for detrital exchange between the marsh and creek waters.

As suggested for the North Inlet system (South Carolina), factors such as the relative degree of marsh flooding, current velocity, phytoplankton concentration and rainfall events influence daily and seasonal variability of POC concentrations (Wolaver et al. 1986). These factors are also considered important at the more temperate Canary Creek system (Table 3). Tide height (a measure of relative marsh surface flooding) was positively correlated with POC concentration in all seasonal sample periods, except January when the marsh surface was frozen. This clearly suggests that inundation of the marsh surface influences material concentrations. The process of creekbank erosion in influencing POC concentrations is indicated by significant positive correlations with current velocity. The role of rainshower events and storms as controlling factors is presented in a later section of this paper.

For DOC, no seasonal trends are apparent. Mean ebb tide DOC concentration was consistently higher than mean flood tide concentration for all studies, although

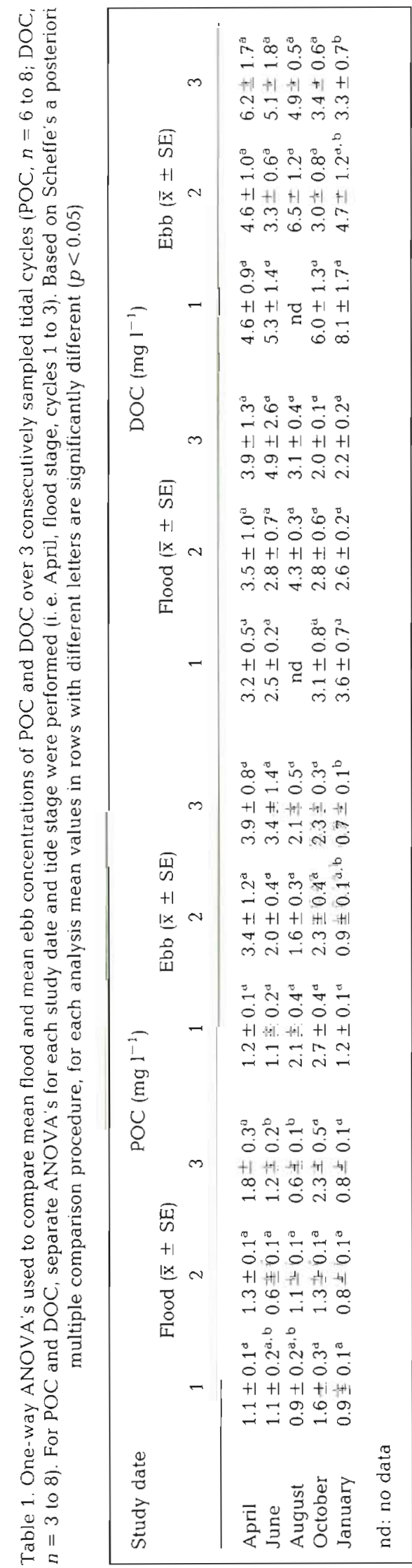


Table 2. One-way ANOVA's used to determine differences in mean flood and mean ebb concentrations of POC and DOC by study date (POC, $n=16$ to 21 ; DOC, $n=9$ to 20 ). Tidal stages were analysed separately. Based on Scheffe's a posteriori multiple comparison procedure, mean values in columns with different letters are significantly different $(p<0.05)$. Significant differences between mean flood and mean ebb concentrations for each study date were determined by $t$-test $(" p<0.05)$

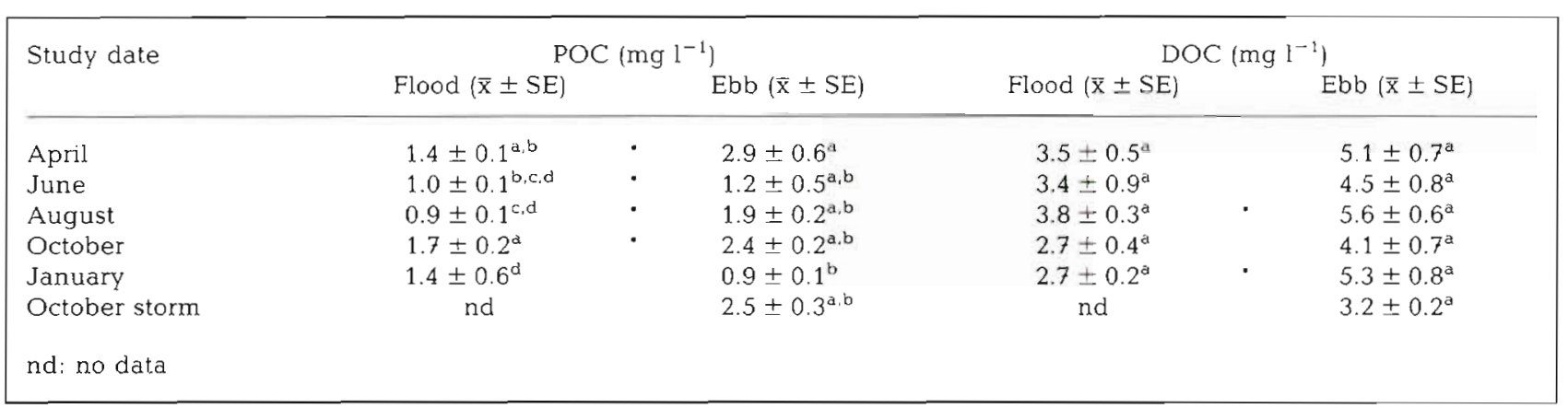

Table 3. Correlation analysis of hourly POC concentrations versus tide height, mean cross-sectional current velocity, and chlorophyll a concentration. Significant correlation coefficients are shown (" $p<0.05 ; \cdots p<0.01$; df $=36$ to 38$)$

\begin{tabular}{|c|c|c|c|}
\hline Study date & Height & $\begin{array}{l}\text { Factors } \\
\text { Velocity }\end{array}$ & Chl a \\
\hline April & $0.36^{\circ}$ & & $0.61 \cdots$ \\
\hline June & $0.42^{\cdots}$ & & $0.49^{\circ}$ \\
\hline August & $0.48^{\cdots}$ & $0.78^{*}$ & \\
\hline October & $0.50^{\cdots}$ & $0.57^{\circ}$ & $0.75 \cdots$ \\
\hline January & & $0.51^{\cdots}$ & $0.38^{\circ}$ \\
\hline
\end{tabular}

the difference was only significant in August and January (Table 2).

The particle size distribution of $\mathrm{POC}$ reveals that on ebb tides, as opposed to flood tides, a greater percentage of the particulate material was $>20 \mu \mathrm{m}$ in size, except in June when the trend was not statistically significant (Table 4). Bioturbation may be playing an important role in the processing and suspending of detrital materials within the marsh ecosystem, especially during the warm months when up to $40 \%$ of the total POC was within the larger size fractions. Ward (1981) found suspended material concentrations to double from winter to summer in a South Carolina marsh, suggesting that biological activity was an important controlling factor.

The size distribution of Canary Creek detrital materials has widespread implications in terms of utilization by estuarine consumers. The dominance of suspended particulates within a size range of $<20 \mu \mathrm{m}$ (Table 4 ) complements the small particle size preference (1 to $10 \mu \mathrm{m}$ ) of filter-feeding mollusks (Møhlenberg \& Riisgård 1978, Palmer \& Williams 1980). Wilson (1973), studying Acartia tonsa, a dominant copepod in the Delaware Bay estuary, found that it has the ability to select larger particles (up to $70 \mu \mathrm{m}$ ) over smaller, yet more abundant, particles. These studies stress the concept that a broad spectrum of detrital materials are utilized by estuarine consumers.

Table 4. One-way ANOVA's used to determine differences in mean flood and mean ebb size fraction data ( $n=7$ to 10 observations) by study date. Data are presented as percent contribution of each fraction to the cumulative total concentration of POC. Tidal stages were analysed separately. Based on Scheffe's a posteriori multiple comparison procedure, mean values in columns with different letters are significantly different $(p<0.05)$. Significant differences between mean flood and mean ebb percentages for each study date were determined by $t$-test $\left({ }^{\circ} p<0.05\right)$

\begin{tabular}{|c|c|c|c|c|c|c|c|c|}
\hline \multirow[t]{2}{*}{ Study date } & \multicolumn{2}{|c|}{$243 \mu \mathrm{m}$} & \multicolumn{2}{|c|}{$243-63 \mu \mathrm{m}$} & \multicolumn{2}{|c|}{$63-20 \mu \mathrm{m}$} & \multicolumn{2}{|c|}{$20 \mu \mathrm{m}$} \\
\hline & $\begin{array}{c}\text { Flood } \\
(\bar{x} \pm \mathrm{SE})\end{array}$ & $\begin{array}{c}E b b \\
(\bar{x} \pm S E)\end{array}$ & $\begin{array}{c}\text { Flood } \\
(\bar{x} \pm S E)\end{array}$ & $\begin{array}{c}E b b \\
(\bar{x} \pm S E)\end{array}$ & $\begin{array}{c}\text { Flood } \\
(\bar{x} \pm S E)\end{array}$ & $\begin{array}{c}E b b \\
\{\bar{x} \pm S E\}\end{array}$ & $\begin{array}{c}\text { Flood } \\
(\bar{x} \pm S E)\end{array}$ & $\begin{array}{c}E b b \\
(\bar{x} \pm S E)\end{array}$ \\
\hline April & 5. $\pm 1.5^{\mathrm{a}}$ & $6.4 \pm 1.1^{a}$ & $5.1 \pm 1.2^{\mathrm{a}}$ & $9.1 \pm 1.5^{a . b}$ & $7.0 \pm 1.1^{a}$ & $10.2 \pm 1.0^{1}$ & $84.2 \pm 2.1^{d}$ & $75.1 \pm 3.2^{\circ}$ \\
\hline June & $3.7 \pm 1.5^{\mathrm{a}}$ & $\cdot 10.1 \pm 2.0^{\mathrm{a}, \mathrm{b}}$ & $12.3 \pm 1.7^{b . c}$ & $15.1 \pm 2.4^{a, b}$ & $11.1 \pm 1.1^{a, b}$ & $14.2 \pm 1.1^{a}$ & $73.0 \pm 3.2^{a}$ & $62.3 \pm 4.6^{a, b}$ \\
\hline August & $1.3 \pm 1.3^{\mathrm{d}}$ & - $8.6 \pm 2.0^{\alpha}$ & $5.8 \pm 1.7^{a, b}$ & $11.3 \pm 2.7^{a . b}$ & $12.1 \pm 1.3^{a . b}$ & $12.2 \pm 1.5^{\mathrm{a}}$ & $81.0 \pm 2.7^{\mathrm{a}}$ & $\cdot 64.3 \pm 4.9^{a b}$ \\
\hline October & $6.4 \pm 1.0^{\mathrm{a}}$ & $12.4 \pm 3.0^{a, b}$ & $7.5 \pm 1.1^{\mathrm{a} . c} \cdot$ & $15.7 \pm 2.2^{\mathrm{d} . b}$ & $9.0 \pm 0.7^{a \cdot b}$ & $11.6 \pm 1.7^{\mathrm{a}}$ & $77.1 \pm 1.9^{4}$ & $\cdot 60.3 \pm 5.9^{a, b}$ \\
\hline January & $1.7 \pm 1.1^{\mathrm{a}}$ & $4.8 \pm 1.5^{\mathrm{a}}$ & $4.4 \pm 1.9^{\mathrm{a}}$ & $7.8 \pm 1.6^{a}$ & $15.5 \pm 2.0^{\mathrm{b}}$ & $15.7 \pm 1.2^{a}$ & $81.4 \pm 3.2^{a}$ & $\cdot 71.7 \pm 2.4^{a}$ \\
\hline October storm & nd & $23.9 \pm 6.6^{\mathrm{b}}$ & nd & $24.7 \pm 6.5^{b}$ & nd & $14.2 \pm 1.8^{\mathrm{a}}$ & nd & $37.3 \pm 12.4^{b}$ \\
\hline
\end{tabular}


Table 6. Seasonal flux budgets for POC and DOC. Values are means of 3 consecutive tidal cycles

\begin{tabular}{|c|c|c|c|}
\hline Study date & Tide $^{d}$ & $\begin{array}{c}\text { POC } \\
\left(\mathrm{kg} \mathrm{cycle} e^{-1}\right)\end{array}$ & $\begin{array}{c}\text { DOC } \\
\left(\mathrm{kg} \mathrm{cycle}^{-1}\right)\end{array}$ \\
\hline April & $\begin{array}{l}F \\
E \\
N\end{array}$ & $\begin{array}{r}253 \\
-513 \\
-260\end{array}$ & $\begin{array}{r}527 \\
-827 \\
-300\end{array}$ \\
\hline June & $\begin{array}{l}F \\
E \\
N\end{array}$ & $\begin{array}{r}231 \\
-354 \\
-123\end{array}$ & $\begin{array}{r}648 \\
-606 \\
42\end{array}$ \\
\hline August & $\begin{array}{l}F \\
E \\
N\end{array}$ & $\begin{array}{r}212 \\
-536 \\
-324\end{array}$ & $\begin{array}{r}977 \\
-1144 \\
-127\end{array}$ \\
\hline October & $\begin{array}{l}F \\
E \\
N\end{array}$ & $\begin{array}{r}518 \\
-580 \\
-62\end{array}$ & $\begin{array}{r}663 \\
-879 \\
-216\end{array}$ \\
\hline January & $\begin{array}{l}F \\
E \\
N\end{array}$ & $\begin{array}{r}223 \\
-183 \\
40\end{array}$ & $\begin{array}{r}413 \\
-1002 \\
-589\end{array}$ \\
\hline
\end{tabular}

est DOC concentration (15.5 $\left.\mathrm{mg}^{-1}\right)$ was recorded during the January study. The contribution of DOC to creek waters from these components has been quantified (aboveground Spartina leachate: Gallagher et al. 1976, Pakulski 1986; marsh porewater: Howes et al. 1985, Yelverton \& Hackney 1986). Upland runoff may be another significant source of DOC to the marshestuarine system, as suggested for the North Inlet system (Wolaver et al. 1986).

To calculate annual transport budgets for POC and DOC between the marsh and Delaware Bay, the year was divided into 5 periods, each with a field sampling interval at the midpoint. A limitation of this annual estimate is the assumption that transport during each tidal cycle of a period was equal to the mean value estimated during the respective sampling of consecutive tidal cycles. Accepting this assumption, POC and DOC were exported from the 190 ha Canary Creek marsh at rates of $1.05 \times 10^{5} \mathrm{~kg} \mathrm{yr}^{-1}$ and $1.97 \times 10^{5} \mathrm{~kg}$ $\mathrm{yr}^{-1}$, respectively. Transport of floating macrodetritus and bedload materials was not included in this estimate. However, Dame \& Stilwell (1984), studying the North Inlet system, found that carbon exported as floating detritus was minimal, and further, they postulated that net bedload transport would also be minimal.

\section{Storms}

Storms are often considered as significant events controlling marsh-estuarine exchange processes and detritus budgets. Two contrasting types of storm events were monitored in this study. Thundershowers, common events in spring and summer, are shown to influence material exchange both during the actual event and during tidal cycles subsequent to the shower event (Fig. 1). During the April study, an intense shower

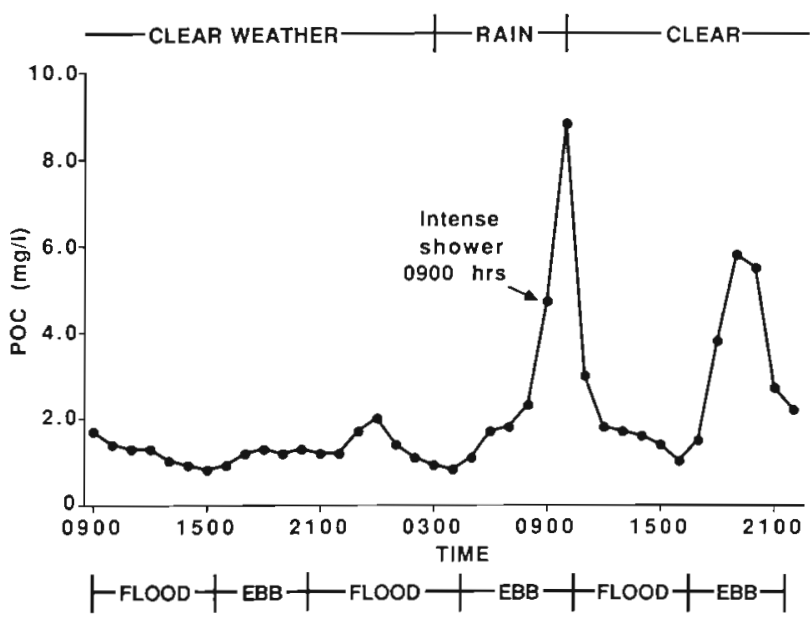

Fig. 1. Pattern of hourly particulate organic carbon (POC) concentration over 3 consecutive tidal cycles monitored in April. Note the peak in concentration after an intense shower during the late ebb, followed by another peak in the third ebb cycle

occurred toward the end of the ebb cycle, resulting in elevated POC concentrations. The next ebb cycle also revealed elevated concentrations suggesting that the shower effectively loosened and dislodged materials which were then re-suspended by flood waters, and ultimately exported from the system. The potential influence of these episodic shower events on marsh sedimentological and organic material exchange processes has also been observed by others (Settlemyre \& Gardner 1975, Harriss et al. 1980, Ward 1981, Jordon et al. 1986, Wolaver et al. 1986). Rainshowers may represent an important mechanism for keeping POC available to consumers rather than it being incorporated into marsh sediments (Chalmers et al. 1985).

Sampling during major coastal storms has generally eluded scientists, thus allowing only speculative conclusions concerning their influence on material transport. On 25 October 1980 material exchange was monitored during a tropical storm. Sampling was conducted hourly from high slackwater to low slackwater; a period of $9 \mathrm{~h}$. The flooding storm surge could not be sampled; however, it is fortuitous that a planned sample period (21 to 22 October) took place just prior to this storm event. Ebb tide data from this normal sample period are compared with data from the storm ebb. Over $1 \times 10^{6} \mathrm{~m}^{3}$ of water was discharged from the system, a volume about 5 times greater than the aver- 


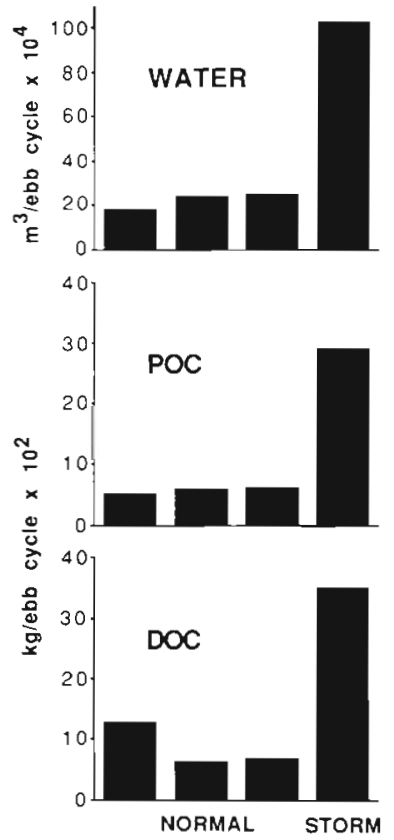

Fig. 2. Transport of water, particulate organic carbon and dissolved organic carbon during normal and storm ebb tide conditions in October

age ebb tidal prism of the normal period (Fig. 2). Due to this large volume, a significant dilution of $\mathrm{POC}$ and DOC would be expected, yet this was not the case (Table 2). From the size fraction results it is seen that $49 \%$ of the POC was $>63 \mu \mathrm{m}$, ca 2 times greater than during the normal October ebb cycles (Table 4). These larger fractions contained plant fragments, particularly root/rhizome parts, suggesting a vigorous flushing of the marsh surface (it is estimated that the marsh surface was covered with over $1 \mathrm{~m}$ of wateri, coupled with erosional processes incising the surface peat. Since no flood data were collected net transport could not be calculated, but it is interesting to note that ebb tide transport of POC and DOC was 5 to 6 times greater than during normal ebb cycles (Fig. 2). These data, coupled with those of Pickral \& Odum (1977) and Hackney \& Bishop (1981), support the contention that during major coastal storms considerable quantities of organic materials may be exported from salt marshes.

Acknowledgements. This research was supported in part by the Delaware Sea Grant Program and the Center for Coastal and Environmental Studies at Rutgers University

\section{LITERATURE CITED}

Boon, J. D. (1975). Tidal discharge asymmetry in a salt marsh drainage system. Limnol. Oceanogr. 20: 71-80

Boon, J. D. (1978). Suspended solids transport in a salt marsh creek - an analysis of errors. In: Kjerfve, B. (ed.) Estuarine transport processes. University of South Carolina Press, Columbia, p. 147-159

Chalmers, A. G., Wiegert, R. G., Wolf, P. L. (1985). Carbon balance in a salt marsh: interactions of diffusive export, tidal deposition and rainfall-caused erosion. Estuar coast. Shelf Sci 21.757-771

Chrzanowski, T H., Stevenson, L. H., Spurrier, J. D. (1982). Transport of particulate organic carbon through the North Inlet ecosystem. Mar Ecol. Prog. Ser. 7: 231-245

Dame, R., Chrzanowski, T., Bildstein, K., Kjerfve, B., McKellar, H., Nelson, D., Spurrier, J., Stancyk, S., Stevenson, H., Vernberg, J., Zigmark, R. (1986). The outwelling hypothesis and North Inlet, South Carolina. Mar. Ecol. Prog. Ser. 33: 217-229

Dame, R. F., Stilwell, D. (1984). Environmental factors influencing macrodetritus flux in North Inlet Estuary. Estuar coast. Shelf Sci. 18: 721-726

Erkenbrecker, C. W., Stevenson, L. H. (1978). The transport of microbial biomass and suspended material in a highmarsh creek. Can. J. Microbiol. 24: 839-846

Gallagher, J. L., Pfejffer, W. J., Pomeroy, L. R. (1976). Leaching and microbial utilization of dissolved organic matter from leaves of Spartina alterniflora. Estuar. coast. mar. Sci. 4: $467-471$

Hackney, C. T., Bishop, T. D. (1981). A note on the relocation of marsh debris during a storm surge. Estuar, coast. Shelf Sci. 12: 621-624

Haines, E. B. (1977). The origins of detritus in Georgia salt marshes. Oikos 29: 254-260

Harriss, R. C., Ribelin, B. W., Dreyer, C. (1980). Sources and variability of suspended particulates and organic carbon in a salt marsh estuary. In: Hamilton, P., Macdonald, K. B. (eds.) Estuarme and wetland processes: with emphasis on modeling. Marine Science Vol. 11 Plenum Press, New York, p. 371-384

Howes, B. L., Dacey, J. W H., Teal, J. M. (1985). Annual carbon mineralization and belowground production of Spartina alterniflora in a New England salt marsh. Ecology 66: 595-605

Jordan, T E., Pierce, J. W., Correll, D. L. (1986). Flux of particulate matter in the tidal marshes and subtidal shallows of the Rhode River Estuary. Estuaries 9: 310-319

Kjerfve, B., Proehl, J. A. (1979). Velocity variability in a crosssection of a well-mixed estuary. J. mar Res. 37: 409-418

Kjerfve, B., Stevenson, L. H., Proehl, J. A., Chrzanowski, T. H. (1981). Estimation of material fluxes in an estuarine crosssection: a critical analysis of spatial measurement density and errors. Limnol Oceanogr. 26: 325-335

Menzel, D. W. Vaccaro, R. F. (1964). The measurement of dissolved organic and particulate carbon in seawater. Limnol. Oceanogr. 9: 138-142

Møhlenberg, R., Riisgård, H. U. (1978). Efficiency of particle retention in 13 species of suspension feeding bivalves. Ophelia 18: 239-246

Nixon, S. W (1980). Between coastal marshes and coastal waters - a review of twenty years of speculation and research on the role of salt marshes in estuarine productivity and water chemistry. In: Hamilton, P., Macdonald, K. B. (eds.) Estuarine and wetland processes: with emphasis on modeling. Marine Science Vol. 11. Plenum Press, New York, p. 437-525

Odum, E. P., de la Cruz, A. A. (1967). Particulate organic detritus in a Georgia salt marsh-estuarine ecosystem. In: Lauff, G. H. (ed.) Estuaries. AAAS, Publ. No. 83, Washington, D.C., p. $383-388$

Pakulski, J. D. (1986). The release of reducing sugars and dissolved organic carbon from Spartina alterniflora Loisel 
in a Georgia salt marsh. Estuar. coast. Shelf Sci. 22: 385-394

Palmer, R. E., Williams, L. G. (1980). Effect of particle concentration on filtration efficiency of the Bay Scallop Argopecten irradians and the Oyster Crassostrea virginica. Ophelia 19: $163-174$

Pickral, J. C., Odum, W. E. (1977). Benthic detritus in a salt marsh tidal creek. In: Wiley, M. L. (ed.) Estuarine processes, Vol. II. Academic Press, New York, p. 280-292

Roman, C. T (1984). Estimating water volume discharge through salt-marsh tidal channels: an aspect of material exchange. Estuaries 7: 259-264

Roman, C. T., Daiber, F. C. (1984). Aboveground and belowground primary production dynamics of two Delaware Bay tidal marshes. Bull. Torrey bot. Club 111: 34-41

Settlemyre, J. L., Gardner, L. R. (1975). Low-tide storm erosion in a salt marsh. Southeast. Geol 16: 205-212

Sharp J. H. (1973). Total organic carbon in seawater - comparison of measurements using persulphate oxidation and high temperature combustion. Mar. Chem. 1: 211-229

Sharp, J. H. (1974). Improved analysis for 'particulate' organic carbon and nitrogen from seawater. Limnol. Oceanogr 19: 984-989

Strickland, J. D. H., Parsons, T. R. (1972). A practical handbook of seawater analysis. Bull. Fish. Res. Bd Can. 167

Valiela, I., Teal, J. M., Volkmann, S. B., Cogswell, C. M., Harrington, R. A. (1980). On the measurement of tidal

This article was presented by Professor S. W. Nixon, Kingston, Rhode Island, USA exchanges and groundwater flow in sait marshes. Limnol. Oceanogr. 25: 187-192

Valiela, I., Teal, J. M., Volkmann, S., Shafer, D., Carpenter, E. J. (1978). Nutrient and particulate fluxes in a salt marsh ecosystem: tidal exchanges and inputs by precipitation and groundwater. Limnol. Oceanogr. 23: 798-812

Ward, L. G. (1981). Suspended-material transport in marsh tidal channels, Kiawah Island, South Carolina. Mar. Geol. 40: $139-154$

Whiting, G. J., McKellar, H. N., Jr., Kjerfve, B., Spurrier, J. D. (1985). Sampling and computational design of nutrient flux from a southeastern U.S. saltmarsh. Estuar. coast. Shelf Sci. 21: 273--286

Wilson, D. S. (1973). Food size selection among copepods. Ecology 54: 909-914

Wolaver, T. G., Hutchinson, S., Marozas, M. (1986). Dissolved organic carbon and particulate organic carbon in the North Inlet estuary, South Carolina - what controls these concentrations? Estuaries 9: 31-38

Woodwell, G. M., Whitney, D. E., Hall, C. A. S., Houghton, R. A. (1977). The Flax Pond ecosystem study: exchange of carbon in water between a salt marsh and Long Island Sound. Limnol. Oceanogr. 22: 823-828

Yelverton, G. F., Hackney, C. T (1986). Flux of dissolved organic carbon and pore water through the substrate of a Spartina alterniflora marsh in North Carolina. Estuar coast. Shelf Sci. 22: 255-267

Manuscript first received: November 5, 1987

Revised version accepted: March 16, 1989 